\title{
Herbicide-Assisted Restoration of Great Basin Sagebrush Steppe Infested With Medusahead and Downy Brome
}

\author{
Guy B. Kyser, ${ }^{1}$ Robert G. Wilson, ${ }^{2}$ Jimin Zhang, ${ }^{3}$ and Joseph M. DiTomaso ${ }^{4}$
}

Authors are ${ }^{1}$ Specialist, ${ }^{3}$ Postdoctoral Researcher, and ${ }^{4}$ Cooperative Extension Specialist, Department of Plant Sciences, University of California, Davis, Davis, CA 95616, USA; and ${ }^{2}$ Director and Farm Advisor, University of California Intermountain Research and Extension Center, Tulelake, CA 96134, USA.

\begin{abstract}
Downy brome or cheatgrass (Bromus tectorum) and medusahead (Taeniatherum caput-medusae) are the most problematic invasive annual grasses in rangelands of the western United States, including sagebrush communities that provide habitat to sage grouse. Rehabilitation of infested sites requires effective weed control strategies combined with seeding of native plants or desirable competitive species. In this study, we evaluated the effect of three fall-applied pre-emergence herbicides (imazapic, rimsulfuron, and chlorsulfuron+sulfometuron), and one spring-applied postemergence herbicide (glyphosate) on the control of downy brome and medusahead and the response of seeded perennial species and resident vegetation in two sagebrush communities in northeastern California. All pre-emergence treatments gave $>93 \%$ control of both invasive species at both sites in the first year. Glyphosate was less consistent, giving $>94 \%$ control at one site and only $61 \%$ control of both species at the other site. Imazapic was the only herbicide to maintain good control (78-88\%) of both species 2 yr after treatment. No herbicide caused detectible long-term damage to either perennial grasses or annual forbs, and imazapic treatment resulted in an increase in resident native forb cover $3 \mathrm{yr}$ after treatment. Broadcast seeding with or without soil incorporation did not result in successful establishment of perennial species, probably due to below-average precipitation in the year of seeding. These results indicate that several chemical options can give short-term control of downy brome and medusahead. Over the course of the study, imazapic provided the best management of both invasive annual grasses while increasing native forb cover.
\end{abstract}

Key Words: annual grass, imazapic, invasive, rangeland, revegetation

\section{INTRODUCTION}

Sagebrush steppe communities in the Great Basin of Nevada and northeastern California are susceptible to invasion by noxious annual grasses such as medusahead (Taeniatherum caput-medusae [L.] Nevski) and downy brome or cheatgrass (Bromus tectorum L.). Downy brome, in particular, is the most widespread invasive plant in the United States, occupying over 22 million ha in the 17 western states (Duncan et al. 2004). Although not as widespread, medusahead is the second most harmful invasive annual grass in the western United States, infesting nearly 1 million ha.

Both species have had significant economic and ecological impacts on western rangelands. For example, medusahead has low nutrient value, a rough texture, and a high silica content $(>10 \%$ of dry weight) that greatly reduce its palatability. A dense infestation may decrease rangeland grazing capacity by as much as $80 \%$ (Hironaka 1961). In addition, the high silica content in its foliage slows the rate of decomposition, which leads to a persistent thatch that suppresses germination and establishment of other rangeland species, reducing the population densities of a number of native functional groups (Davies

\footnotetext{
This research was funded in part by the USDA Area-wide Demonstration of Ecologicallybased IPM of Annual Grass Ecosystems in the Great Basin.

Correspondence: Joseph M. DiTomaso, Dept of Plant Sciences, Mail Stop 4, University of California, One Shields Ave, Davis, CA 95616, USA. Email: jmditomaso@ucdavis. edu
}

Manuscript received 17 December 2012; manuscript accepted 24 June 2013

(c) 2013 The Society for Range Management and Svejcar 2008; Young and Mangold 2008). Although downy brome is considered far better forage compared to medusahead, it can be undependable as a source of feed for cattle and sheep depending on climatic conditions (Knapp 1996). Like medusahead, it can also reduce plant and animal biodiversity in heavily infested areas (Rosentrater 1994; Young 2000). Most importantly, both invasive annual grasses are known to reduce fire-return intervals in sagebrush scrub to $<5$ yr. This ecosystem is not adapted to frequent burning, with the result that the scrub community is eventually displaced by an exotic annual grass community (Whisenant 1990).

As a consequence of their impacts on sagebrush (Artemisia spp.) and associated plant species, both medusahead and downy brome have been shown to reduce wildlife habitat. This has resulted in dramatic losses in some threatened species, such as sage grouse (Centrocercus urophasianus and C. minimus) and other sagebrush obligates (Wirth and Pyke 2003). Sage grouse populations depend not only on sagebrush (Connelly et al. 2000), but also on associated forb forage species (Wirth and Pyke 2003). The total area of sagebrushgrassland habitat and the species diversity in much of the remaining habitat have declined for at least the last $50 \mathrm{yr}$ (Connelly et al. 2000). While a number of factors contribute to this decline, the most severe appears to be habitat conversion resulting from the invasion of exotic annual grasses, particularly downy brome and medusahead (Crawford et al. 2004).

Numerous studies have shown the importance of managing annual weeds such as medusahead and downy brome prior to establishing desirable species in rangeland (e.g., Velagala et al. 1997; Sheley et al. 2007; Davies 2010; Wilson et al. 2010). Conversely, once competitive resident vegetation or seeded 
species become established, they can play an important role in restricting the reinvasion of medusahead or downy brome (Sheley et al. 2007).

The successful use of herbicides to assist in community type conversion depends on the abundance of desirable resident native shrubs, forbs, and perennial grasses at the site prior to treatment (Monaco et al. 2005; Kyser et al. 2007; Sheley et al. 2007), or on the introduction of suitable revegetation species. In this study, we hypothesized that densities of downy brome and medusahead would be reduced by an appropriate herbicide application, with a resultant improvement in establishment of native species. Several herbicides have been shown to give short-term control of downy brome and medusahead. For example, rimsulfuron has been shown to control medusahead and downy brome in greenhouse and rangeland trials in the western United States (Butler et al. 2007; Alford et al. 2008; Hirsch et al. 2012). The combination of sulfometuron + chlorsulfuron has mixed selectivity; at higher rates $(158+79 \mathrm{~g}$ $\mathrm{ai} \cdot \mathrm{ha}^{-1}$ to $315+158 \mathrm{~g} \mathrm{ai} \cdot \mathrm{ha}^{-1}$ ) this treatment controls many grass, broadleaf, and brush species, but at lower rates it has been shown to control medusahead and downy brome while being relatively safe to other species (Butler et al. 2007). Glyphosate, although nonselective at conventional use rates, can be broadcast at low rates to control annual species, such as medusahead and downy brome, while causing minimal damage to established perennials (J. E. Creech, personal communication; Kyser et al. 2012).

Of the herbicides used to control invasive annual grasses, imazapic shows the most promise in restoration of medusahead or downy brome infested rangelands in the Great Basin region of the western United States (Beran et al. 2000; Masters et al. 2001; Barnes 2004). Imazapic has a fairly long soil residual with an average half-life of $120 \mathrm{~d}$ (Senseman 2007), and thus has the potential to control weeds throughout the initial establishment of a revegetation planting. It has been shown to be particularly effective on both downy brome (Dewey et al. 2003; Sebastian and Beck 2004; Wilson et al. 2010) and medusahead (Shinn and Thill 2002; Monaco et al. 2005; Wilson et al. 2010). In addition, imazapic is safe on many species of perennial grasses, including several wheatgrass (Agropyron spp.) species (Shinn and Thill 2004), as well as sagebrush (Morris et al. 2009). However, weed control and selectivity for desirable species with imazapic can vary depending on precipitation, soil type (Morris et al. 2009), and thatch buildup (Kyser et al. 2007).

Establishment of desirable, competitive vegetation is a critical element in an integrated weed management program (Borman et al. 1991; Lym and Tober 1997), and has been shown to be important for restoration of Great Basin sagebrush grouse habitat (Eiswerth et al. 2009). In a location that is not severely degraded (i.e., which has robust populations of native species), short-term integrated management may be accomplished by controlling invasive weeds and allowing natives to reestablish. While this is the most desirable and economical situation, revegetation often requires a more active seeding program. On Great Basin rangeland, broadcast seeding of perennial grasses or forbs is generally unsuccessful. Drill seeding may improve the chances of establishment, owing to increased seed-to-soil contact (Harper et al. 1965). Nevertheless, most seeding efforts have a low success rate, and thus revegetation is the primary obstacle to successful integrated weed management on sagebrush rangeland.

In this study, we evaluated the long-term effects of rimsulfuron, imazapic, sulfometuron+chlorsulfuron, and glyphosate for management of downy brome and medusahead, and for recovery of resident native vegetation. In addition to evaluating weed management without seeding, we also included two seeding methods and two seed mixes as part of an integrated revegetation strategy. We hypothesized that one or more of our integrated strategies would be successful in increasing desirable species and improving sage grouse habitat.

\section{METHODS}

\section{Site Description}

We established experiments at two sites in the Smoke Creek region of eastern Lassen County, California, approximately 50 $\mathrm{km}$ WNW of Susanville and $7.5 \mathrm{~km}$ apart. Both study sites have been designated by the US Bureau of Land Management as high-priority areas for restoration of sage grouse habitat. The sites were designated as Bull Flat (lat $40.49^{\circ} \mathrm{N}$, long $120.13^{\circ} \mathrm{W}$, $1450 \mathrm{~m}$ elevation) and Bull Fire (lat $40.52^{\circ} \mathrm{N}$, long $120.05^{\circ} \mathrm{W}$, $1450 \mathrm{~m}$ elevation). This area is high desert, at the southern end of the Modoc Plateau and at the western rim of the Great Basin. The plant community is sagebrush steppe dominated by Wyoming big sagebrush (Artemisia tridentata Nutt. ssp. wyomingensis Beetle \& A.L. Young). Soils at both sites are in the Horsecamp series (fine, smectitic, mesic Aridic Haploxererts). They are deep, well-drained, silty clay soils weathered from basaltic material, with abundant volcanic cobbles throughout, and $0.5 \%$ organic matter in the top $30 \mathrm{~cm}$ (USDA-NRCS 2012).

Eleven-yr mean precipitation at these sites is $195 \mathrm{~mm}$. Climate data were obtained from a Remote Automatic Weather Station $1.6 \mathrm{~km}$ from the Bull Flat site and $7.2 \mathrm{~km}$ from the Bull Fire site (Western Regional Climate Center 2012). June to July precipitation in 2008-2009, 2009-2010, and 2010-2011 was $135 \mathrm{~mm}, 139 \mathrm{~mm}$, and $260 \mathrm{~mm}$, respectively (Fig. 1). The yearly mean temperature is $9.7^{\circ} \mathrm{C}$, with mean minimums of $-4.6^{\circ} \mathrm{C}$ from November through April; during the years of this study, temperatures were close to average. While there was no previous record of fire on the Bull Flat site, the Bull Fire site burned in February 2007.

Bull Flat was characterized by $\sim 1 \%$ big sagebrush cover and $3-5 \%$ cover of perennial grasses, primarily quackgrass (Elymus repens [L.] Gould,=Elytrigia repens [L.] Nevski). The Bull Fire site had $5-10 \%$ big sagebrush cover on the western half (replications 1 and 2) and 1\% sagebrush cover on the eastern half (replications 3 and 4). Bull Fire had 1-2\% cover of perennial grasses, primarily squirreltail (Elymus elymoides [Raf.] Swazey). At the beginning of this study, both sites had $2-3 \%$ cover of herbaceous broadleaf species, mostly the native bristly fiddleneck (Amsinckia tessellata A. Gray), a scattering of other native species, and some nonnative mustards, particularly flixweed (Descurainia sophia [L.] Webb ex Prantl) and tumble mustard (Sisymbrium altissimum L.). Initial cover estimates are based on quadrat measurements in untreated plots (procedure described in "Treatment Evaluation" section). 


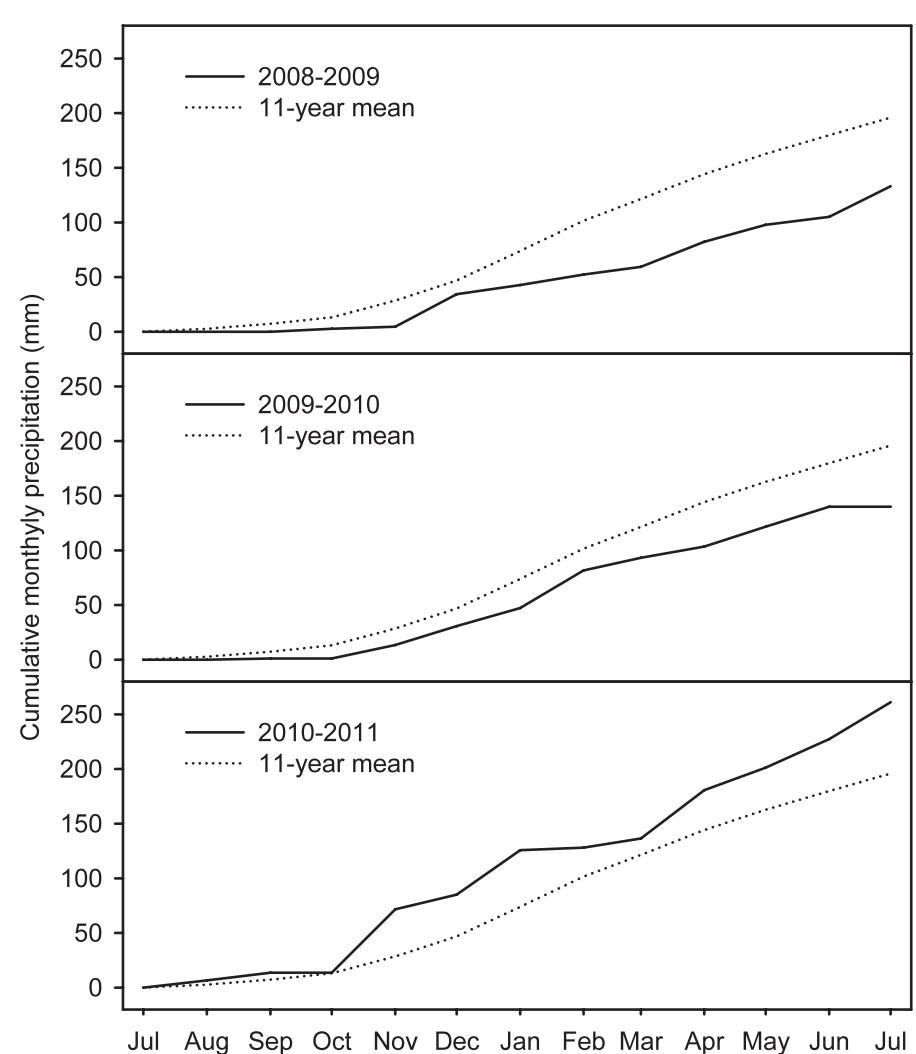

Figure 1. Cumulative annual precipitation at Bull Flat and Bull Fire from July to June 2008-2009, 2009-2010, and 2010-2011. Dotted lines represent mean precipitation from 2002 to 2012.

\section{Plot Design and Treatment}

At each site we established 20 plots in a $4 \times 5$ grid. Individual plots were $30 \times 30 \mathrm{~m}$. Cattle were excluded from both sites. Five herbicide treatments, including an untreated control, were arranged in a randomized complete block design with four replications at each site (Table 1). Three treatments with soilresidual herbicides were applied 23-24 October 2008, before annual grass emergence. The herbicides in these treatments were rimsulfuron (Matrix), imazapic (Plateau), and sulfometuron+chlorsulfuron (Landmark XP; Table 1); these treatments also included $0.25 \% \mathrm{v} / \mathrm{v}$ nonionic surfactant (Activator 90, Loveland Products, Inc, Greeley, CO). Glyphosate (Roundup), which does not have soil residual activity, was applied 22 April 2009, when annual grasses were 3 to $8 \mathrm{~cm}$ tall. We added ammonium sulfate to the glyphosate treatment at $12 \mathrm{~g} \cdot \mathrm{L}^{-1}$ of spray solution. All treatments were applied in $150 \mathrm{~L} \cdot \mathrm{ha}^{-1}$ spray solution using $\mathrm{CO}_{2}$ backpack sprayers.

Plots were seeded 30 September 2009, approximately 1 yr after application of the soil residual herbicides, to reduce potential for injury to the seeded species. Five seeding treatments were applied: two seed mixes in two planting methods, plus an unseeded control. One seed mix included two native perennial grasses, $6.7 \mathrm{~kg} \cdot \mathrm{ha}^{-1}$ 'Secar' bluebunch wheatgrass (Elymus wawawaiensis J. Carlson \& Barkworth; 90\% germinable) and $3.4 \mathrm{~kg} \cdot \mathrm{ha}^{-1}$ 'Rosana' western wheatgrass (Pascopyrum smithii [Rydb.] Á. Löve; 89\% germinable). The other seed mix included a nonnative perennial grass, 6.7 $\mathrm{kg} \cdot \mathrm{ha}^{-1}$ 'Hycrest' crested wheatgrass (Agropyron cristatum [L.] Gaertn. $\times A$. desertorum [Fisch. ex Link] Schult.; 82\% germinable). All seeding treatments also included $1.1 \mathrm{~kg} \cdot \mathrm{ha}^{-1}$ Wyoming big sagebrush collected locally ( $93 \%$ germinable). Seed mixes were planted by two methods (broadcast seeding with or without incorporation). Seeding treatments were established in 6-m wide subplot strips running the length of each plot replication. Seeding strips were randomized within each replication. Incorporation was done with a blanket harrow pulled by an all-terrain vehicle.

\section{Treatment Evaluation}

Plots were evaluated in June of 2009, 2010, and 2011. We modified the sampling protocols each year following inspection of the previous year's data. In 2009, we randomly placed five $0.1-\mathrm{m}^{2}$ quadrats per plot and recorded percent cover of all species and counts of medusahead and downy brome seedheads. We clipped and dried the material at $60^{\circ} \mathrm{C}$ for $14 \mathrm{~d}$ and weighed total biomass from each quadrat. In 2010, after establishing the seeding treatments, we placed three $0.1-\mathrm{m}^{2}$ quadrats per subplot (each seeded strip), for a total of 15 quadrats per plot, and recorded the same parameters as in 2009, including biomass. In 2011, following analysis of 2010 data that showed no significant effect of the seeding treatments, we randomly placed eight $1-\mathrm{m}^{2}$ quadrats per plot and recorded percent cover of all species.

\section{Analysis}

Mean values of all quadrats in each plot or subplot were used in analysis. Medusahead and downy brome cover and seedhead counts were analyzed individually while cover estimates were summed for perennial grasses, native broadleaf species, and introduced broadleaf species. In order to handle normality and variance issues in the first year's (2009) data, we compared treatment effects using nonparametric analysis. We first used Van der Waerden tests of each response variable to find $\chi^{2}$ probabilities of differences among all treatments. For response variables showing significant differences $\left(\chi^{2}\right.$ probability $<0.05)$, we used Wilcoxon tests to determine differences among treatment pairs. In 2010, we had generally better-structured data and were able to perform ANOVA for a split-plot design with treatment and seeding as factors, and treatment by seeding as a random factor. (Although it was obvious that seeding establishment was poor, we performed this analysis to see if there were any detectible effects of the seeding process on the rest of the plant community.) This analysis showed no effect of seeding treatments on any of the variables, so for consistency we parsed means with nonparametric tests as above, using means for all quadrats from each plot (total 15 quadrats per plot). For 2011, we performed nonparametric tests as above. All analyses were performed using JMP 8.0 (SAS Institute 2008).

\section{RESULTS}

Seeding did not result in significant establishment or in changes in cover of resident plant species, regardless of the seed mix, incorporation method, or study site. As such, data from all seeding strips were combined for each herbicide treatment plot. 
Table 1. Herbicide treatment rates and timing, product formulations, and sources.

\begin{tabular}{|c|c|c|c|c|c|c|}
\hline \multirow[b]{2}{*}{ Treatment } & \multirow{2}{*}{$\begin{array}{l}\text { Rate } \\
\left(\mathrm{g} \cdot \mathrm{ha}^{-1}\right)\end{array}$} & \multirow{2}{*}{$\begin{array}{l}\text { Application } \\
\text { timing }\end{array}$} & \multicolumn{3}{|c|}{ Commercial product } & \multirow[b]{2}{*}{ Source } \\
\hline & & & Trade name & Formulation & Concentration & \\
\hline Glyphosate & 420 ae & $\begin{array}{r}22 \text { April } \\
2009\end{array}$ & $\begin{array}{l}\text { Roundup } \\
\text { Original }\end{array}$ & $\begin{array}{l}\text { aqueous } \\
\text { solution }\end{array}$ & $359 \mathrm{~g}$ ae $\cdot \mathrm{L}^{-1}$ & $\begin{array}{l}\text { Monsanto Company, St. Louis, M0 } \\
\text { (http://www.monsanto.com) }\end{array}$ \\
\hline Imazapic & $105 \mathrm{ae}$ & $\begin{array}{l}24 \text { October } \\
2008\end{array}$ & Plateau & $\begin{array}{l}\text { aqueous } \\
\text { solution }\end{array}$ & $240 \mathrm{~g}$ ae $\cdot \mathrm{L}^{-1}$ & $\begin{array}{l}\text { BASF Corporation, Research Triangle Park, NC } \\
\text { (http://www.basf.com/group/corporate/en) }\end{array}$ \\
\hline Rimsulfuron & 70 ai & $\begin{array}{l}24 \text { October } \\
2008\end{array}$ & Matrix & $\begin{array}{l}\text { water soluble } \\
\text { granule }\end{array}$ & $25 \%$ & $\begin{array}{l}\text { DuPont Crop Protection, Wilmington, DE } \\
\text { (http://www2.dupont.com/Prod_Agriculture/en-us/content/crop-protection.html) }\end{array}$ \\
\hline $\begin{array}{l}\text { Sulfometuron } \\
\quad+\text { chlorsulfuron }\end{array}$ & $35+18$ ai & $\begin{array}{l}24 \text { October } \\
2008\end{array}$ & $\begin{array}{l}\text { Landmark } \\
\qquad \mathrm{XP}\end{array}$ & $\begin{array}{l}\text { dispersible } \\
\text { granule }\end{array}$ & $50 \%+25 \%$ & $\begin{array}{l}\text { DuPont Crop Protection, Wilmington, DE } \\
\text { (http://www2.dupont.com/Prod_Agriculture/en-us/content/crop-protection.html) }\end{array}$ \\
\hline Untreated & - & - & - & - & - & - \\
\hline
\end{tabular}

\section{Medusahead and Downy Brome Control}

At Bull Flat, downy brome was the dominant invasive annual grass (Table 2). In the first evaluation after treatment (2009), treatments reduced downy brome cover by 93-100\%. Cover increased by the second evaluation (2010) but was still significantly lower in treated plots. In 2010, sulfometuron+chlorsulfuron reduced downy brome cover and seedhead density by $93 \%$ and $99 \%$, respectively. Imazapic and glyphosate also continued to reduce cover $(87 \%$ and $91 \%$, respectively) and seedhead density (95\% and 97\%, respectively). Rimsulfuron reduced downy brome cover and seedhead density in $2010(77 \%$ and $85 \%$, respectively), but was less effective than sulfometuron+chlorsulfuron or glyphosate. In the third evaluation (2011), only imazapic and glyphosate reduced downy brome cover compared to untreated plots (by 50\% and $44 \%$, respectively). Medusahead was a relatively minor component at Bull Flat, with maximum cover of $2.2 \% \pm 0.8 \%$ SE (untreated plots in 2009). In the first evaluation, all herbicide treatments gave nearly complete control of medusahead.

At the Bull Fire site (Table 3), medusahead and downy brome were codominant. In 2009, all soil residual treatments reduced medusahead cover (94-100\%) and seedhead density (96$100 \%)$. The glyphosate treatment was less effective, reducing cover by $61 \%$ and seedhead density by $48 \%$. In 2010 , only imazapic continued to control medusahead, reducing cover by $68 \%$ and seedhead density by $74 \%$ (though the latter effect was not statistical). By 2011, medusahead cover in imazapic, rimsulfuron, and glyphosate plots was not significantly different from untreated plots, and actually increased in sulfometuron + chlorsulfuron plots. We attribute this to a decrease in total density of medusahead seedlings due to the treatment, which resulted in reduced intraspecific competition and more robust medusahead plants in these plots in 2011 (personal observation). The sites received higher than average rainfall this year $(+33 \%)$, and medusahead in the sulfometuron + chlorsulfuron treated plots remained green and photosynthetic long after annual grasses in the other plots had senesced.

In the first evaluation at Bull Fire (2009), downy brome responses were similar to those of medusahead (Table 3). Soil residual treatments reduced downy brome cover and seedhead density by 99-100\%, whereas glyphosate reduced cover and seedhead density by $61 \%$ and $53 \%$, respectively. Downy brome control remained significant for all treatments in the second evaluation (2010), with imazapic, rimsulfuron, and sulfome- turon + chlorsulfuron giving the best control. In particular, imazapic reduced downy brome cover by $88 \%$ and seedhead density by $95 \%$. Although control was not as good in the third evaluation (2011), imazapic, rimsulfuron, and sulfometuron+ chlorsulfuron still reduced downy brome cover compared to untreated plots. Imazapic plots had the lowest downy brome cover, $65 \%$ of the cover in untreated plots.

Although medusahead and downy brome cover differed between the two sites, cover expressed as a percentage relative to untreated plots showed similar trends (Figs. 2 and 3). At Bull Fire, medusahead cover increased over time in all treatments, relative to untreated plots (Fig. 2). While each herbicide treatment gave excellent control in the first evaluation (2009), medusahead recovered more slowly in imazapic plots and still had significantly lower cover than untreated plots in 2010 . Downy brome cover relative to untreated plots also showed consistent trends at both sites, with the exception of plots treated with glyphosate (Fig. 3). At both sites, plots treated with rimsulfuron or sulfometuron + chlorsulfuron recovered to $61-75 \%$, relative to untreated plots, by the third evaluation. Plots treated with imazapic maintained better control, recovering only to $35-50 \%$. Results with glyphosate were inconsistent at the two sites. At Bull Flat, glyphosate was fairly successful, reducing downy brome cover to only $5 \%$ of untreated plots in the first evaluation (2009), and to $56 \%$ by the third evaluation (2011). At Bull Fire, in contrast, 2009 cover was $39 \%$ of untreated plots and 2011 cover was $85 \%$.

\section{Response of Other Species}

Perennial Grasses. Perennial grass cover at Bull Flat ranged from $3 \%$ to $12 \%$ over all treatments and all years (Table 2 ) compared to Bull Fire, with 0-2\% cover (Table 3). At Bull Flat, there were no statistical differences in perennial grass cover among treatments in any of the 3 yr. Even the spring application of glyphosate, which is considered nonselective, had no effect on total cover of perennial grasses. This is likely because the treatment was applied before perennial grasses began to grow rapidly. Quackgrass, one of the perennial grasses at Bull Flat, has been shown to have a reduced response to glyphosate in low-temperature applications (Harker and Dekker 1988), as have a number of other species. At Bull Fire, perennial grass cover was low and variable and did not show a statistical response to treatments. 
Table 2. Vegetation response to treatments at Bull Flat over 3 yr of evaluation. Chi square values reflect results of Van der Waerden test (nonparametric analysis) with treatment as the independent factor; " $P>\chi^{2}$ " is the probability that differences occurred by chance. Means were compared using pairwise Mann-Whitney tests; values followed by the same letter are not different for each column within each year $(\alpha=0.05)$. Because analyses were performed on individual cover classes, total cover is reported but was not analyzed (n/a). In 2011, seedhead densities and biomass were not measured (n/m).

\begin{tabular}{|c|c|c|c|c|c|c|c|c|c|}
\hline \multirow{3}{*}{$\begin{array}{c}\text { Year (date of evaluation), } \\
\text { treatment }\end{array}$} & \multirow{2}{*}{\multicolumn{2}{|c|}{ Medusahead }} & \multirow{2}{*}{\multicolumn{2}{|c|}{ Downy brome }} & \multicolumn{3}{|c|}{ Percent cover of other species } & \multirow{3}{*}{$\begin{array}{l}\text { Total } \% \\
\text { cover }\end{array}$} & \multirow{3}{*}{$\begin{array}{c}\text { Total biomass } \\
\left(\mathrm{g} \cdot \mathrm{m}^{-2}\right)\end{array}$} \\
\hline & & & & & Perennial & Introduced & Native & & \\
\hline & $\%$ cover & Seedheads $\cdot \mathrm{m}^{-2}$ & $\%$ cover & Seedheads $\cdot \mathrm{m}^{-2}$ & grasses & forbs & forbs & & \\
\hline \multicolumn{10}{|l|}{2009 (15-17 June) } \\
\hline Imazapic & $0.1 \mathrm{~b}$ & $0.5 \mathrm{~b}$ & $0.8 \mathrm{bc}$ & $9.5 \mathrm{~b}$ & 4.2 & $0 \mathrm{~b}$ & 0.1 & 5.1 & $17.0 \mathrm{bc}$ \\
\hline Rimsulfuron & $0 \mathrm{~b}$ & $0 \mathrm{~b}$ & $0 \mathrm{c}$ & $0 \mathrm{~b}$ & 5.3 & $0 \mathrm{~b}$ & 2.0 & 7.3 & $32.3 \mathrm{ab}$ \\
\hline Sulfometuron + chlorsulfuron & $0 \mathrm{~b}$ & $0 \mathrm{~b}$ & $0 \mathrm{c}$ & $0 \mathrm{~b}$ & 3.2 & $0 \mathrm{~b}$ & 0 & 3.2 & $6.4 \mathrm{c}$ \\
\hline Glyphosate & $0 \mathrm{~b}$ & $0 \mathrm{~b}$ & $0.7 \mathrm{bc}$ & $17.0 \mathrm{~b}$ & 4.8 & $0.2 \mathrm{~b}$ & 0.1 & 5.7 & $11.6 \mathrm{c}$ \\
\hline Untreated & $2.2 \mathrm{a}$ & $46.0 \mathrm{a}$ & $11.2 \mathrm{a}$ & 395.0 a & 4.3 & $2.2 \mathrm{a}$ & 0.3 & 20.1 & $40.8 \mathrm{a}$ \\
\hline$P>\chi^{2}$ & 0.040 & 0.042 & 0.021 & 0.032 & 0.81 & 0.029 & 0.17 & $n / a$ & 0.020 \\
\hline \multicolumn{10}{|l|}{2010 (28-30 June) } \\
\hline Imazapic & $0.6 \mathrm{a}$ & 1.7 & $3.5 \mathrm{bc}$ & $22.5 \mathrm{c}$ & 11.6 & $1.2 \mathrm{c}$ & 0.9 & 17.7 & $47.1 \mathrm{~b}$ \\
\hline Rimsulfuron & $0.7 \mathrm{a}$ & 6.5 & $6.0 \mathrm{~b}$ & $67.3 \mathrm{~b}$ & 10.3 & $4.1 \mathrm{ab}$ & 1.1 & 22.3 & $81.1 \mathrm{a}$ \\
\hline Sulfometuron + chlorsulfuron & $0.1 \mathrm{~b}$ & 0.2 & $1.8 \mathrm{c}$ & $5.5 d$ & 11.9 & $0.3 \mathrm{c}$ & 0.5 & 14.6 & $30.8 \mathrm{c}$ \\
\hline Glyphosate & $0.2 \mathrm{~b}$ & 1.0 & $2.8 \mathrm{c}$ & $13.5 \mathrm{~cd}$ & 8.1 & $8.1 \mathrm{a}$ & 0.9 & 20.1 & $54.2 \mathrm{~b}$ \\
\hline Untreated & $0.8 \mathrm{a}$ & 3.7 & $26.6 \mathrm{a}$ & $437.0 \mathrm{a}$ & 5.9 & $2.2 \mathrm{bc}$ & 1.6 & 37.1 & $107.8 \mathrm{a}$ \\
\hline$P>\chi^{2}$ & 0.017 & 0.36 & 0.014 & 0.013 & 0.11 & 0.020 & 0.32 & $n / a$ & 0.006 \\
\hline \multicolumn{10}{|l|}{2011 (6-8 June) } \\
\hline Imazapic & 0.2 & $\mathrm{n} / \mathrm{m}$ & $25.7 \mathrm{C}$ & $\mathrm{n} / \mathrm{m}$ & 7.8 & 21.8 & $5.2 \mathrm{a}$ & 60.7 & $\mathrm{n} / \mathrm{m}$ \\
\hline Rimsulfuron & 0.8 & $\mathrm{n} / \mathrm{m}$ & $38.8 \mathrm{~b}$ & $\mathrm{n} / \mathrm{m}$ & 5.9 & 23.1 & $0.5 \mathrm{~b}$ & 69.1 & $\mathrm{n} / \mathrm{m}$ \\
\hline Sulfometuron + chlorsulfuron & 1.0 & $\mathrm{n} / \mathrm{m}$ & $37.8 \mathrm{~b}$ & $\mathrm{n} / \mathrm{m}$ & 6.2 & 23.4 & $0.1 \mathrm{~b}$ & 68.4 & $\mathrm{n} / \mathrm{m}$ \\
\hline Glyphosate & 0.4 & $\mathrm{n} / \mathrm{m}$ & $29.0 \mathrm{C}$ & $\mathrm{n} / \mathrm{m}$ & 5.1 & 24.7 & $1.0 \mathrm{~b}$ & 60.1 & $\mathrm{n} / \mathrm{m}$ \\
\hline Untreated & 0.3 & $\mathrm{n} / \mathrm{m}$ & $51.7 \mathrm{a}$ & $\mathrm{n} / \mathrm{m}$ & 4.6 & 5.0 & $0.8 \mathrm{~b}$ & 62.5 & $\mathrm{n} / \mathrm{m}$ \\
\hline$P>\chi^{2}$ & 0.16 & - & 0.020 & - & 0.73 & 0.058 & 0.020 & $n / a$ & - \\
\hline
\end{tabular}

Native and Introduced Forbs. Unlike perennial grasses, forbs showed significant treatment responses. In the first evaluation (2009), total forb cover was low $(\leq 2.5 \%)$ in all treatments at both sites, with the highest cover in untreated plots. We postulate that this was due to low rainfall (69\% of average). All treatments reduced cover of introduced forbs at both sites, but had no significant effect on native forbs (Tables 2 and 3).

The next year (2010) was also dry overall, with $71 \%$ of average precipitation. However, rainfall from April to June 2010 was $60 \%$ higher than rainfall during April to June 2009, about equal to the 11-yr mean for that interval. Probably for this reason, total forb cover in untreated plots was considerably higher at both sites in 2010, 3.8\% $\pm 0.4 \%$ SE at Bull Flat (Table 2) and $12.9 \% \pm 0.6 \%$ SE at Bull Fire (Table 3). At Bull Flat, introduced forb cover was different only in the glyphosate treatment, where it was nearly four times higher than in untreated plots (Table 2). This was primarily due to an increase in introduced mustards (flixweed and tumble mustard). There were no significant differences in native forb cover. At Bull Fire in 2010, rimsulfuron significantly increased the cover of both introduced and native forbs, imazapic reduced introduced forbs, and sulfometuron + chlorsulfuron reduced native forbs (Table 3).

In the third evaluation (2011), following a precipitation season $33 \%$ above the $11-y r$ mean, total forb cover in untreated plots was similar to 2010 at both sites: $5.8 \% \pm 1.7 \%$ SE at Bull Flat and $12.0 \% \pm 0.9 \%$ SE at Bull Fire. At Bull Flat, all treated plots had higher overall forb cover compared to untreated plots; all treatments tended to increase cover of introduced forbs (not statistical), and the imazapic treatment also increased native forb cover by 6.5 times compared to untreated plots. At Bull Fire in 2011, imazapictreated plots had 2.5 times the cover of native forbs compared to untreated plots, primarily bristly fiddleneck. In contrast, sulfometuron + chlorsulfuron plots had significantly increased cover of introduced forbs.

Herbicide treatments significantly reduced total biomass at both Bull Flat (Table 2) and Bull Fire (Table 3) in 2009. This difference was maintained at Bull Flat in 2010, but not at Bull Fire. At Bull Fire, rimsulfuron-treated plots had higher total biomass compared to untreated plots or any other treatment, owing to a significant increase in forbs. Biomass was not taken in 2011. Total vegetative cover followed similar patterns, but because this was a composite variable it was not analyzed.

\section{DISCUSSION}

Broadcast seeding in September 2009, with or without incorporation, did not result in successful establishment of perennials in 2010. This may have been due to below-average precipitation in the season after seeding. Seeding these species in a wetter year (e.g., 2011) likely would have resulted in greater establishment. Young et al. (1999) suggest that revegetation in the intermountain region succeeds only rarely, in the occurrence of a "mythical wet spring." It might also be 
Table 3. Vegetation response to treatments at Bull Fire over 3 yr of evaluation. Chi square values reflect results of Van der Waerden test (nonparametric analysis) with treatment as the independent factor; " $P>\chi$ " is the probability that differences occurred by chance. Means were compared using pairwise Mann-Whitney tests; values followed by the same letter are not different for each column within each year $(\alpha=0.05)$. Because analyses were performed on individual cover classes, total cover is reported but was not analyzed (n/a). In 2011, seedhead densities and biomass were not measured (n/m).

\begin{tabular}{|c|c|c|c|c|c|c|c|c|c|}
\hline \multirow{3}{*}{$\begin{array}{c}\text { Year (date of evaluation), } \\
\text { treatment }\end{array}$} & \multirow{2}{*}{\multicolumn{2}{|c|}{ Medusahead }} & \multirow{2}{*}{\multicolumn{2}{|c|}{ Downy brome }} & \multicolumn{3}{|c|}{ Percent cover of other species } & \multirow{3}{*}{$\begin{array}{c}\text { Total } \% \\
\text { cover }\end{array}$} & \multirow{3}{*}{$\begin{array}{c}\text { Total biomas } \\
\left(\mathrm{g} \cdot \mathrm{m}^{-2}\right)\end{array}$} \\
\hline & & & & & Perennial & Introduced & Native & & \\
\hline & $\%$ cover & Seedheads $\cdot \mathrm{m}^{-2}$ & $\%$ cover & Seedheads $\cdot \mathrm{m}^{-2}$ & grasses & forbs & forbs & & \\
\hline \multicolumn{10}{|l|}{2009 (15-17 June) } \\
\hline Imazapic & $0.7 \mathrm{bc}$ & $8.0 \mathrm{c}$ & $0.2 \mathrm{c}$ & $3.0 \mathrm{c}$ & 0.5 & 0 & 0 & 1.3 & $6.2 \mathrm{bc}$ \\
\hline Rimsulfuron & $0.1 \mathrm{c}$ & $1.0 \mathrm{c}$ & $0 \mathrm{c}$ & $0 \mathrm{c}$ & 1.1 & 0 & 0.1 & 1.3 & $11.3 \mathrm{~b}$ \\
\hline Sulfometuron + chlorsulfuron & $0 \mathrm{c}$ & $0 \mathrm{c}$ & $0 \mathrm{c}$ & $0 \mathrm{c}$ & 0 & 0 & 0 & 0 & $0 \mathrm{c}$ \\
\hline Glyphosate & $4.4 \mathrm{~b}$ & $114.0 \mathrm{~b}$ & $7.9 \mathrm{~b}$ & $331.0 \mathrm{~b}$ & 0 & 0 & 0.6 & 12.9 & $12.2 \mathrm{~b}$ \\
\hline Untreated & $11.3 \mathrm{a}$ & $221.0 \mathrm{a}$ & $20.2 \mathrm{a}$ & $709.5 \mathrm{a}$ & 1.6 & 0.8 & 1.2 & 35.0 & $42.6 \mathrm{a}$ \\
\hline$P>\chi^{2}$ & 0.026 & 0.016 & 0.0077 & 0.012 & 0.057 & 0.066 & 0.14 & $n / a$ & 0.0082 \\
\hline \multicolumn{10}{|l|}{2010 (28-30 June) } \\
\hline Imazapic & $5.9 \mathrm{~b}$ & 69.3 & $1.4 \mathrm{c}$ & $14.0 \mathrm{c}$ & 1.6 & $0.1 \mathrm{c}$ & $18.7 \mathrm{ab}$ & 27.8 & $85.4 \mathrm{~b}$ \\
\hline Rimsulfuron & $13.6 \mathrm{a}$ & 223.5 & $3.5 \mathrm{bc}$ & $32.2 \mathrm{c}$ & 1.5 & $6.3 \mathrm{a}$ & 25.7 a & 50.6 & $156.4 \mathrm{a}$ \\
\hline Sulfometuron + chlorsulfuron & $14.6 \mathrm{a}$ & 207.8 & $2.8 \mathrm{C}$ & $35.5 \mathrm{c}$ & 2.3 & $0.4 \mathrm{bc}$ & $4.4 \mathrm{C}$ & 24.6 & $74.0 \mathrm{~b}$ \\
\hline Glyphosate & $14.4 \mathrm{a}$ & 251.2 & $6.2 \mathrm{~b}$ & $160.0 \mathrm{~b}$ & 1.1 & $1.3 \mathrm{~b}$ & $15.2 \mathrm{~b}$ & 38.2 & $100.3 b$ \\
\hline Untreated & $18.4 \mathrm{a}$ & 264.0 & $11.9 \mathrm{a}$ & $292.2 \mathrm{a}$ & 1.0 & $1.3 \mathrm{~b}$ & $11.6 \mathrm{~b}$ & 44.2 & $79.0 \mathrm{~b}$ \\
\hline$P>\chi^{2}$ & 0.050 & 0.065 & 0.030 & 0.010 & 0.064 & 0.0082 & 0.0030 & $n / a$ & 0.014 \\
\hline \multicolumn{10}{|l|}{2011 (6-8 June) } \\
\hline Imazapic & $16.4 \mathrm{~b}$ & $\mathrm{n} / \mathrm{m}$ & $11.6 \mathrm{~d}$ & $\mathrm{n} / \mathrm{m}$ & 1.7 & $1.3 \mathrm{~b}$ & $26.2 \mathrm{a}$ & 57.2 & $\mathrm{n} / \mathrm{m}$ \\
\hline Rimsulfuron & $23.9 \mathrm{~b}$ & $\mathrm{n} / \mathrm{m}$ & $22.1 \mathrm{bc}$ & $\mathrm{n} / \mathrm{m}$ & 1.8 & $1.6 \mathrm{~b}$ & $10.0 \mathrm{~b}$ & 59.5 & $\mathrm{n} / \mathrm{m}$ \\
\hline Sulfometuron + chlorsulfuron & $38.3 \mathrm{a}$ & $\mathrm{n} / \mathrm{m}$ & $19.7 \mathrm{c}$ & $\mathrm{n} / \mathrm{m}$ & 0.8 & $6.1 \mathrm{a}$ & $14.6 \mathrm{~b}$ & 79.5 & $\mathrm{n} / \mathrm{m}$ \\
\hline glyphosate & $17.6 \mathrm{~b}$ & $\mathrm{n} / \mathrm{m}$ & $27.8 \mathrm{~b}$ & $\mathrm{n} / \mathrm{m}$ & 1.1 & $3.0 \mathrm{~b}$ & $10.9 \mathrm{~b}$ & 60.4 & $\mathrm{n} / \mathrm{m}$ \\
\hline untreated & $17.0 \mathrm{~b}$ & $\mathrm{n} / \mathrm{m}$ & $32.7 \mathrm{a}$ & $\mathrm{n} / \mathrm{m}$ & 0.7 & $1.6 \mathrm{~b}$ & $10.4 \mathrm{~b}$ & 62.3 & $\mathrm{n} / \mathrm{m}$ \\
\hline$P>\chi^{2}$ & 0.048 & - & 0.0085 & - & 0.48 & 0.027 & 0.044 & $n / a$ & - \\
\hline
\end{tabular}

argued that poor establishment of seeded species was due, in part, to competition with resident vegetation. However, we consider this unlikely, as total cover in treated plots in 2010 ranged from $18 \%$ to $22 \%$ at Bull Flat and from $25 \%$ to $51 \%$ at Bull Fire (Tables 2 and 3), which presumably should have left space and resources for seedling establishment.

\section{Control of Medusahead and Downy Brome}

In the first evaluation (2009), the pre-emergence herbicides imazapic, rimsulfuron, and chlorsulfuron + sulfometuron gave good, consistent control of medusahead and downy brome. Glyphosate gave effective control at Bull Flat but did not give satisfactory control of either species at Bull Fire. In other studies conducted in the Great Basin, glyphosate rates even lower than those used in this study provided at least $95 \%$ control of medusahead (Kyser et al. 2012) and downy brome (Creech et al., unpublished data). However, the optimal time of application in these studies was somewhat later in the season compared to the treatment timing in this experiment.

In the second evaluation (2010), chlorsulfuron + sulfometuron and glyphosate gave the best control of both species at Bull Flat, but imazapic gave the best control at Bull Fire. Across both sites and species, imazapic gave the most consistent overall control (Figs. 2 and 3). In the third evaluation (2011), imazapic plots had lower cover of both species than other treatments. However, treatment effects were weakening by this point, and differences in cover were not always significant.
Several other reports have shown imazapic to give excellent year-of-treatment control of both downy brome (Dewey et al. 2003; Sebastian and Beck 2004; Kyser et al. 2007; Morris et al. 2009; Wilson et al. 2010) and medusahead (Shinn and Thill 2002; Monaco et al. 2005; Kyser et al. 2007; Wilson et al. 2010). In our study, imazapic also gave good second-year control of both invasive annual grasses. In our third evaluation, control in imazapic plots was detectible but not significant. Likewise, Morris et al. (2009) reported that imazapic did not provide effective control of downy brome in the third year after treatment.

It has been shown that low precipitation during fall can reduce the efficacy of imazapic on annual grasses, probably owing to reduced movement of imazapic in the soil and to reduced germination under low moisture conditions (Morris et al. 2009). Although we had low rainfall in the year of application, our results with imazapic were consistently good at both experimental sites. Another potential limitation to use of imazapic is that it can bind to the litter layer, reducing its availability for plant uptake (Kyser et al. 2007). However, in semi-arid, high-elevation, low-productivity sites as in this study, thatch does not tend to build up (Kyser et al. 2008) and likely does not play a major role in imazapic binding. This may explain why we achieved generally better control of annual grasses with imazapic in this study, compared with our previous studies in low-elevation, high-productivity sites (Kyser et al. 2007).

By reducing weed competition for a period of time, these herbicide treatments can increase the likelihood that seeded 


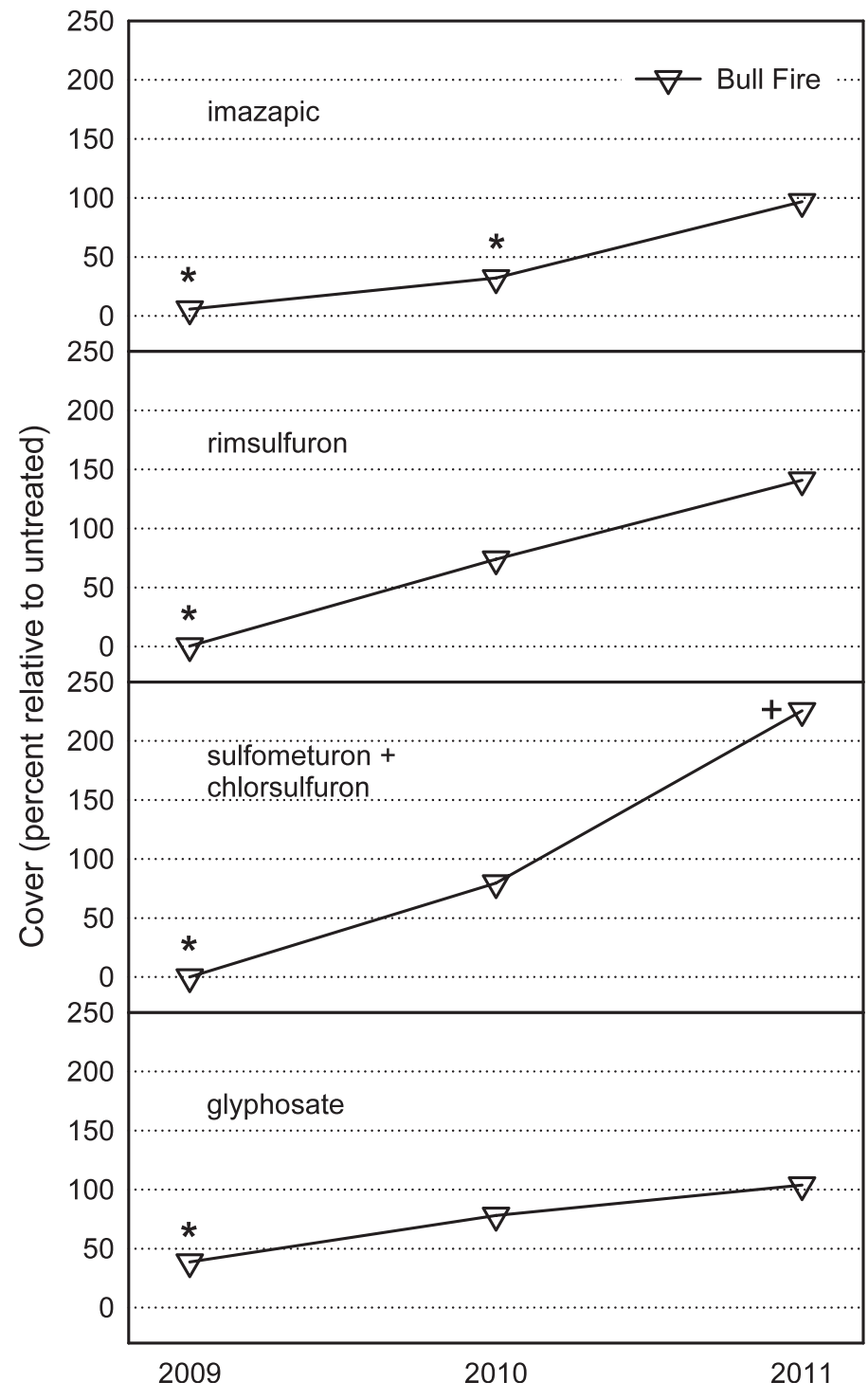

Figure 2. Mean cover of medusahead at Bull Fire, relative to untreated plots, over $3 \mathrm{yr}$ of evaluation. Values are calculated by dividing the mean cover of medusahead in treated plots by the mean cover of medusahead in untreated plots. Data are not included for Bull Flat as mean medusahead cover was too low. Asterisks $\left(^{*}\right)$ indicate that mean cover was significantly lower $(P<0.05)$ than untreated plots, and plus sign $(+)$ indicates mean cover value was significantly higher $(P<0.05)$ than untreated plots.

species will establish. Desirable species can be seeded any time after glyphosate application. However, following application of residual chemicals, herbicide manufacturers recommend delaying seeding of grasses by 3-6 mo, 7-12 mo, or 12 mo for chlorsulfuron + sulfometuron, rimsulfuron, or imazapic, respectively. Seeding in fall 12 mo after applying pre-emergence treatments, as we did in this study, should be an effective strategy for avoiding damage from herbicide residuals. In the subsequent summer, control of medusahead and downy brome should be sufficient to allow seeded species or resident vegetation to establish.

The low rate of glyphosate applied in spring, before most resident species began to grow, was the lowest-cost option we tested. Although this treatment was somewhat inconsis-

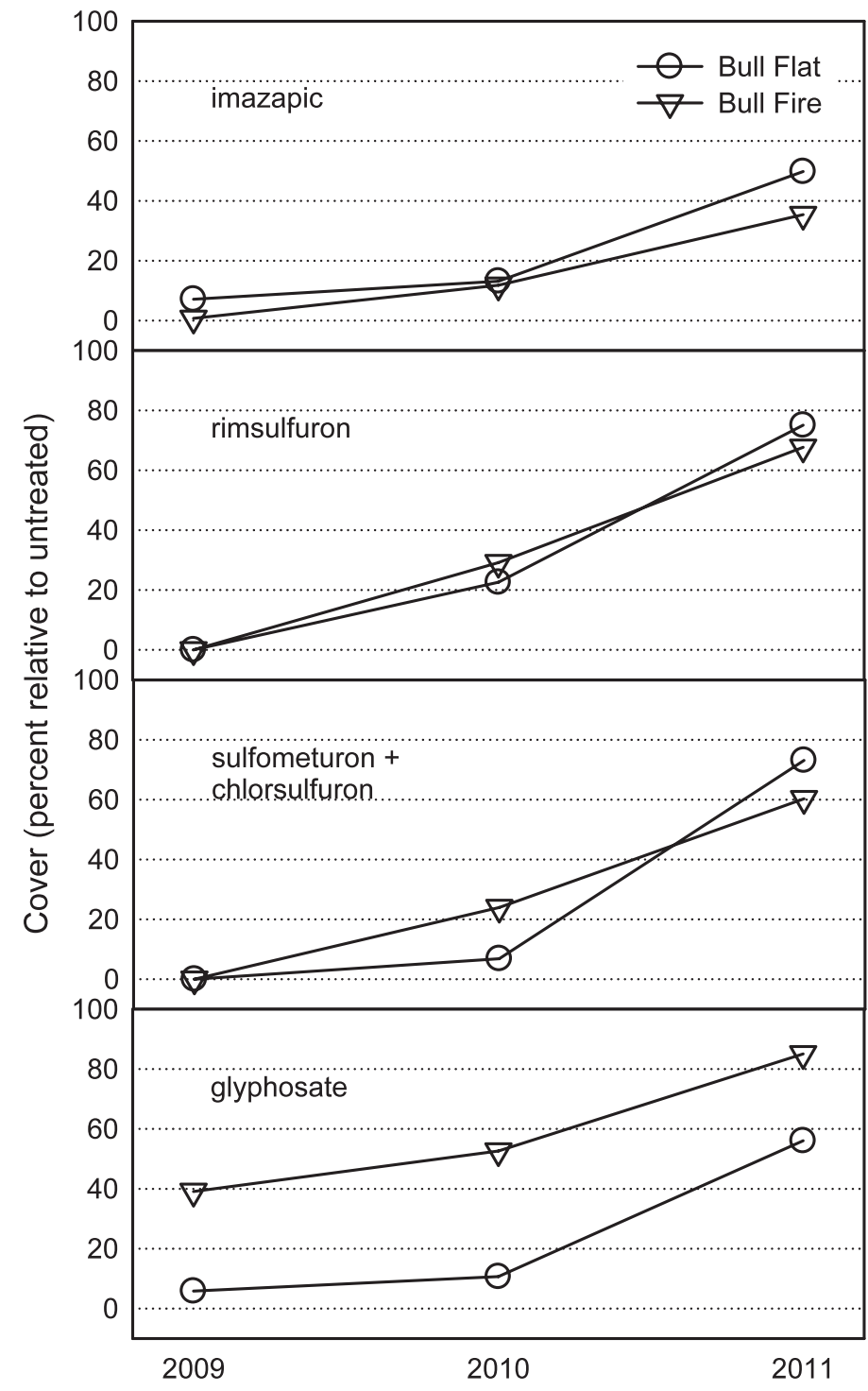

Figure 3. Mean cover of downy brome relative to untreated plots over $3 \mathrm{yr}$ of evaluation. Values are calculated by dividing the mean cover of downy brome in treated plots by the mean cover of downy brome in untreated plots. Cover in all treatments at both sites in all years was significantly lower than respective untreated plots.

tent in this trial, it has been effective in other studies (Kyser et al. 2012; J. Earl Creech, personal communication, 2013). This may be a practical treatment option for medusaheadand downy brome-infested sites with a good population of resident desirable vegetation, as glyphosate leaves no soil residual to hinder same-year establishment of resident species. This would also be the least expensive, and probably the environmentally safest, option if a second year of treatment was needed.

\section{Response of Other Species}

In this study, none of the herbicides tested had long-term detrimental effects on the native vegetation, including perennial grasses, sagebrush, and annual forbs. Imazapic has been shown to be fairly safe on several perennial grasses 
(Shinn and Thill 2004), as well as sagebrush (Morris et al. 2009). Importantly, cover of native forbs increased in imazapic-treated plots. Other studies have also shown high tolerance to imazapic in several native forb species (Beran et al. 1999; Masters et al. 2001), especially species within the Asteraceae and Fabaceae (Kyser et al. 2007). Thus, imazapic in particular can play an important role in restoration of degraded sagebrush communities, provided that desirable resident vegetation is present at levels sufficient to rehabilitate the site over time.

\section{IMPLICATIONS}

This research shows that several herbicides can give excellent short-term selective control of downy brome and medusahead on sagebrush rangeland. At one site, the treatments chlorsulfuron + sulfometuron (applied in fall, pre-emergence) and glyphosate (applied in spring, postemergence) gave the best control of both species in the second year after application. At the other site, imazapic (applied in fall, pre-emergence) gave better control than other treatments in the second year. None of the herbicides tested significantly reduced the cover of perennial grasses or had a long-term impact on forbs. Most notably, imazapic significantly increased the cover of native annual forbs. Over all, imazapic provided the most consistent control of both species in the second year. Treatment differences were no longer significant in the third year, but imazapic-treated plots tended to have the lowest cover of downy brome and medusahead. Thus imazapic would be the best choice for restoring degraded sites with poor stands of resident vegetation if it is necessary to seed the site, especially if only a single herbicide application is economically practical.

Although we succeeded in creating a window for revegetation at these sites, below-average rainfall in the year of seeding resulted in failure to establish perennial grasses or sagebrush. Recruitment continues to be a major obstacle to revegetation of semi-arid sites with unpredictable precipitation.

\section{ACKNOWLEDGMENTS}

We would like to thank Kevin Nicholson of the University of California's Intermountain Research and Extension Center at Tulelake, Carlos Figueroa and Dr Jeremiah Mann at UC Davis, Dr Dan Marcum with UC Cooperative Extension in Shasta and Lassen counties, Alan Uchida with BLM, and Dr Earl Creech with Utah State University for their assistance on the field work and sample analysis. We also thank Dr Mark Weltz, Research Rangeland Management Specialist at USDA-ARS, Reno, for his assistance in locating the research sites. Finally, we thank the Area-Wide Ecologically-Based Invasive Plant Management program based at the USDA-ARS facility in Burns, Oregon, for their financial and scientific support, particularly Dr Roger Sheley.

\section{LITERATURE CITED}

Alford, C. M., R. G. Turner, J. R. Pitts, M. T. Edwards, N. D. McKinley, C. W. Kral, J. D. CANTON, AND R. K. GUTSCHENRITTER. 2008. Fall applications of rimsulfuron in rangelands for the control of downy brome and medusahead. In: Abstracts: Joint Meeting of the Society for Range Management and the America Forage and Grassland Council; 26-
31 January 2008; Louisville, KY, USA. Available at: http://srm.confex.com/srm/ 2008/techprogram/P1863.HTM. Accessed 12 September 2012.

Barnes, T. G. 2004. Strategies to convert exotic grass pastures to tall grass prairie communities. Weed Technology 18:1364-1370.

Beran, D. D., R. A. Masters, R. E. Gaussoin, and F. Rivas-Pantoja. 2000. Establishment of big bluestem and Illinois bundleflower mixtures with imazapic and imazethapyr. Agronomy Journal 92:460-465.

Borman, M. M., W. C. Krueger, and D. E. Johnson. 1991. Effects of established perennial grasses on yields of associated annual weeds. Journal of Range Management 44:318-326.

Butler, M., D. Comingore, and F. Paye. 2007. Control of medusahead and cheatgrass on central Oregon rangelands with Landmark, Matrix, Plateau and Journey, 2006-2007. In: Central Oregon Agricultural Research Center 2007 Annual Report. Corvallis, OR, USA: Oregon State University Agricultural Experiment Station. Special Report 1084. p. 99-101.

Connelly, J. W., M. A. Schroeder, A. R. Sands, and C. E. Braun. 2000. Guidelines to manage sage grouse populations and their habitats. Wildlife Society Bulletin 28:967-985.

Crawford, J. A., R. A. Olson, N. E. West, J. C. Mosley, M. A. Schroeder, T. D. Whitson, R. F. Miller, M. A. Gregg, and C. S. Boyd. 2004. Ecology and management of sagegrouse and sage-grouse habitat. Journal of Range Management 57:2-19.

DaviES, K. W. 2010. Revegetation of medusahead-invaded sagebrush steppe. Rangeland Ecology \& Management 63:564-571.

Davies, K. W., and T. J. SVEJcAR. 2008. Comparison of medusahead invaded and noninvaded Wyoming big sagebrush steppe in southeastern Oregon. Rangeland Ecology \& Management 61:623-629.

Dewey, S. A., R. W. Mace, And T. M. Osmond. 2003. Downy brome control with imazapic on arid rangeland. Newark, CA, USA: Western Society of Weed Science. Research Progress Report. 2 p.

Duncan, C. A., J. J. Jachetta, M. L. Brown, V. F. Carrithers, J. K. Clark, J. M. Ditomaso, R. G. Lym, K. C. McDaniel, M. J. Renz, and P. M. Rice. 2004. Assessing the economic, environmental, and societal losses from invasive plants on rangeland and wildlands. Weed Technology 18:1411-1416.

Eiswerth, M. E., K. Krauter, S. R. Swanson, and M. Zielinski. 2009. Post-fire seeding on Wyoming big sagebrush ecological sites: regression analyses of seeded nonnative and native species densities. Journal of Environmental Management 90:1320-1325.

Harker, K. N., and J. DekKer. 1988. Temperature effects on translocation patterns of several herbicides within quackgrass (Agropyron repens). Weed Science $36: 545-552$.

Harper, J. L., J. T. Willams, and G. A. Sagar. 1965. The behavior of seeds in soil. 1. The terogeneity of soil surfaces and its role in determining the establishment of plants from seed. Journal of Ecology 53:273-286.

Hironaka, M. 1961. The relative rate of root development of cheatgrass and medusahead. Journal of Range Management 14:263-267.

Hirsch, M. C., T. A. Monaco, C. A. Call, and C. V. Ransom. 2012. Comparison of herbicides for reducing annual grass emergence in two Great Basin soils. Rangeland Ecology \& Management 65:66-75.

KnapP, P. A. 1996. Cheatgrass (Bromus tectorum L.) dominance in the Great Basin Desert: history, persistence, and influences to human activities. Global Environmental Change 6:37-52.

Kyser, G. B., J. E. Creech, J. Zhang, and J. M. DiTomaso. 2012. Selective control of medusahead (Taeniatherum caput-medusae) in California sagebrush scrub using low rates of glyphosate. Invasive Plant Science and Management 5:1-8.

Kyser, G. B., J. M. DiTomaso, M. P. Doran, S. B. Orloff, R. G. Wilson, D. L. Lancaster, D. F. LIIE, AND M. L. Porath. 2007. Control of medusahead (Taeniatherum caputmedusae) and other annual grasses with imazapic. Weed Technology 21:65-75.

Kyser, G. B., M. P. Doran, N. K. McDougald, S. B. Orloff, R. N. Vargas, R. G. Wilson, AND J. M. DiTomaso. 2008. Site characteristics determine the success of prescribed burning for medusahead (Taeniatherum caput-medusae) control. Invasive Plant Science and Management 1:376-384.

Lym, R. G., AND D. A. Tober. 1997. Competitive grasses for leafy spurge (Euphorbia esula) reduction. Weed Technology 11:787-792.

Masters, R. A., D. D. Beran, and R. E. Gaussoin. 2001. Restoring tallgrass prairie species mixtures on leafy spurge-infested rangeland. Journal of Range Management 54:362-369. 
Monaco, T. A., T. M. Osmond, and S. A. Dewey. 2005. Medusahead control with falland spring-applied herbicides on northern Utah foothills. Weed Technology 19:653-658.

Morris, C., T. A. Monaco, And C. W. RigBy. 2009. Variable impacts of imazapic rate on downy brome (Bromus tectorum) and seeded species in two rangeland communities. Invasive Plant Science and Management 2:110-119.

Rosentrater, R. 1994. Displacement of rare plants by exotic grasses. In: S. B. Monsen and S. G. Kitchen [EDS.]. Proceedings-ecology and management of annual grasslands. Ogden, UT, USA: USDA Forest Service Intermountain Research Station. General Technical Report INT-GTR-313. p. 170-175.

SAS InStITUTE. 2008. JMP statistics and graphics guide. Version 8.0. Cary, NC, USA: SAS Institute, Inc. 1230 p.

Sebastian, J. R., AND K. G. BeCK. 2004. Downy brome control on Colorado rangeland with imazapic. Newark, CA, USA: Western Society of Weed Science Research. Progress Report. $1 \mathrm{p}$.

Senseman, S. A. [ed.]. 2007. Herbicide Handbook. 9th ed. Lawrence, KS, USA: Weed Science Society of America. $458 \mathrm{p}$.

Sheley, R. L., M. F. Carpinelli, and K. J. Reever Morghan. 2007. Effects of imazapic on target and nontarget vegetation during revegetation. Weed Technology 21:1071-1081.

ShinN, S. L., AND D. C. THILL. 2002. The response of yellow starthistle (Centaurea solstitialis), annual grasses, and smooth brome (Bromus inermis) to imazapic and picloram. Weed Technology 16:366-370.

SHINN, S. L., AND D. C. THILL. 2004. Tolerance of several perennial grasses to imazapic. Weed Technology 18:60-65.

USDA-NRCS. 2012. Web soil survey. Available at: http://websoilsurvey.nrcs.usda. gov/app/. Accessed September 2012.
Velagala, R. P., R. L. Sheley, and J. S. Jacobs. 1997. Influence of density on intermediate wheatgrass and spotted knapweed interference. Journal of Range Management 50:523-529.

Western Regional Climate Center. 2012. Bull Flat data. Available at: http://www.raws. dri.edu/cgi-bin/rawMAIN.pl?caCBUL. Accessed September 2012.

Whisenant, S. G. 1990. Changing fire frequencies on Idaho's Snake River Plains: ecological and management implications. In: E. D. McArthur, E. M. Romney, S. D. Smith and P. T. Tueller [EDS.]. Proceedings-Symposium on cheatgrass invasion, shrub die-off, and other aspects of shrub biology and management; 57 April 1989; Las Vegas, NV, USA. Ogden, UT, USA: USDA Forest Service Intermountain Research Station. General Technical Report INT-276. p. 4-10.

Wilson, R. G., S. B. Orloff, D. L. Lancaster, D. W. Kirby, and H. L. Carlson. 2010. Integrating herbicide use and perennial grass revegetation to suppress weeds in noncrop areas. Invasive Plant Science and Management 3:81-92.

WiRTh, T. A., AND D. A. PYke. 2003. Restoring forbs for sage grouse habitat: fire, microsites, and establishment methods. Restoration Ecology 11:370-377.

Young, J. A. 2000. Bromus tectorum. In: C. C. Bossard, J. M. Randall, and M. C. Hoshovsky [EDS.]. Invasive plants of California's wildlands. Berkeley, CA, USA: University of California Press. p. 76-80.

Young, J. A., C. D. Clements, and G. Nader. 1999. Medusahead and clay: the rarity of perennial seedling establishment. Rangelands 21(6):19-23.

Young, K., And J. Mangold. 2008. Medusahead (Taeniatherum caput-medusae) outperforms squirreltail (Elymus elymoides) through interference and growth rate. Invasive Plant Science and Management 1:73-81. 